\title{
Migrants, Irregular Migrants, or (Irregular) Migrants?
}

\author{
Katharine T. Weatherhead
}

\section{Response to the ATR Debate Proposition: 'It is important and necessary to make clear distinctions between (irregular) migrants, refugees and trafficked persons.' ${ }^{1}$}

Please cite this article as: K T Weatherhead, 'Migrants, Irregular Migrants, or (Irregular) Migrants?', Anti-Trafficking Review, issue 11, 2018, pp. 121-124, www.antitraffickingreview.org

Upon first reading this issue's debate proposition, I was struck by its structure rather than its content. Its content is subject to lively discussions among scholars, practitioners, and policy-makers, as attested to by other contributions in this issue of the journal. Its curious structure, though, raises issues that merit articulation. In what follows, I briefly problematise the bracketing of the word 'irregular' in the debate proposition. What the brackets do is prompt an additional question: migrants, irregular migrants, or (irregular) migrants?

To consider the significance of bracketed text, it is helpful to draw upon the work of Annelise Riles, in which she examines the negotiation of documents at United Nations conferences. ${ }^{2}$ In Riles' analysis, the document under negotiation is not yet an object but is instead a gathering of intentions awaiting consolidation, a focus of thought. ${ }^{3}$ She writes:

"Consensus" among states was manifest in a specific form-that is, in the form of the "clean" and "tight" text, the text without brackets, the text that had not been watered down but rather made strong,

\footnotetext{
1 I am grateful to the journal editors for their helpful comments and suggestions.

2 A Riles, 'Infinity within the Brackets', American Ethnologist, vol. 25, no. 3, 1998, pp. 378-398.

3 Ibid., p. 389.
}

This is an open-access article distributed under the terms of the Creative Commons Attribution License (CC-BY). Under the CC-BY license, the public is free to share, adapt, and make commercial use of the work. Users must always give proper attribution to the authors and the Anti-Trafficking Review. 
precise statements. If the parties reached consensus, the brackets were removed, to the satisfaction and pleasure of all. If any one state refused to agree, however, the brackets remained and people said that the text was "unreadable."

The bracketed text, therefore, is not a 'clean' text. It contains an element of fragility and imprecision.

From this perspective, what was once inconspicuous punctuation in the debate proposition becomes noteworthy. Far from separating the term 'irregular' from its seemingly more crucial context, the brackets draw attention to, invite deliberation on, and compel resolution of the status of irregular as a label.

The category of migrant can be variously defined even within one country, ${ }^{5}$ but in an international context, it broadly applies to people who have moved from one state to another state. It is often qualified to indicate several subcategories of migrant. Irregular migrant is one such sub-category which usually refers to people who have travelled across state borders without authorisation and/or who, even after travelling with authorisation, have stayed in a state against the terms of that authorisation. ${ }^{6}$ Writing '(irregular) migrant', with the brackets, adds ambiguity to the distinction between category and subcategory.

I limit myself to two interpretations of the brackets which respond to this ambiguity. One interpretation emphasises openness. In this interpretation, writing '(irregular) migrant' indicates an awareness of two groups- the broad category of migrant and the sub-category of irregular migrant-which are closely connected but nonetheless different. There is accordingly a freedom to acknowledge their entanglement or to treat them as particular.

4 Ibid.

5 On the United Kingdom, see: B Anderson and S Blinder, 'Who Counts as a Migrant? Definitions and their consequences', Migration Observatory Briefing, University of Oxford, 2017, $5^{\text {th }}$ revision, retrieved 13 December 2017, http:// www.migrationobservatory.ox.ac.uk/wp-content/uploads/2016/04/BriefingWho_Counts_Migrant.pdf.

6 See, for example, the definition of migrant workers in an irregular situation in UN General Assembly, International Convention on the Protection of the Rights of All Migrant Workers and Members of Their Families, 18 December 1990, Article 5. 
Debate drawing upon this first interpretation might exhibit fluidity in how the two categories are used. On the one hand, discussants could acknowledge their entangled nature and thereby disrupt narratives which represent categorisations as self-evident. On the other hand, they might treat them as particular and thereby reinforce the very possibility of categorisation. Either approach is permitted under an open interpretation of the brackets. A consequence is that the fragility and imprecision of the bracketed text continues. The debate proposition is 'unreadable', the parameters are not set, and the ensuing dialogue may be at cross-purposes.

A contrasting, 'cleaner' interpretation emphasises closure. In this interpretation, the brackets dictate a specific reading of the term migrant, which is other than its basic meaning. They instruct 'migrant' to be read as 'irregular migrant', hinting at the equivalence of the terms in this context. A closed interpretation of the brackets narrows the discussion to whether it is important and necessary to make clear distinctions between irregular migrants, refugees, and trafficked persons.

Debate that draws upon this second interpretation counteracts the unreadability of the bracketed text by removing the brackets. The discussion parameters are set. However, equating migrant with irregular migrant risks perpetuating negative connotations of the former term in public discourse. In addition, this approach of a 'tight' text exacerbates the tendency for shorthand to obscure the untidy reality of interactions between people and processes producing a migration status - a status which is not always clear-cut itself. The reductive label of irregular migrant may contribute to the stigmatisation of persons without regular migration status, because it conceals the complexities of each individual's lived experiences.

My point is that there are debates to be had within debates; that the migration field is replete with conceptual wrangling and requires careful navigation. ${ }^{7}$ Concepts direct thought in different ways and have consequences for understanding the varied forms of migration. ${ }^{8}$ It is important and necessary

For an examination of international law to carefully define the term 'mixed migration', see: M Sharpe, 'Mixed Up: International law and the meaning(s) of “mixed migration”, Refugee Survey Quarterly, vol. 37, issue 1, 2018, pp. 116-138.

8 D Turton, 'Conceptualising Forced Migration', Refugee Studies Centre Working Paper No. 12, University of Oxford, 2003, pp. 2-7, retrieved 13 December 2017, https://www.rsc.ox.ac.uk/files/files-1/wp12-conceptualising-forcedmigration-2003.pdf. 
to be attentive to what is bracketed in order to develop a critical awareness of the contestability of categories, the unboundedness of the bounded.

Katharine T. Weatherhead is a $\mathrm{PhD}$ candidate based in the School of Law at Queen Mary University of London. In 2014, she was awarded an MA (Hons) in International Relations and Law from the University of Edinburgh. In 2016, she received an MSc in Refugee and Forced Migration Studies from the University of Oxford. Drawing from the disciplines of both International Relations and Law, Katharine's doctoral research examines the creation of legal knowledge among migrants in the European Union. Email: k.t.weatherhead@qmul.ac.uk. 